\title{
ASOSIASI ANTAR SPESIES FAMILI PALMAE DI KAWASAN AIR TERJUN BAJUIN KABUPATEN TANAH LAUT
}

\author{
Association Between Species of Family Palmae in Bajuin Waterfall Tanah Laut \\ Regency
}

\author{
M. Arsyad \\ Program Studi Pendidikan Biologi Universitas Lambung Mangkurat \\ Jl. Brigjend. H. Hasan Basri No. 87 Kayutangi Banjarmasin 70123 \\ muhammadarsyad@unlam.ac.id
}

\begin{abstract}
Abstrak-Salah satu kawasan wisata di Kabupaten Tanah Laut adalah Air Terjun Bajuin. Kawasan Wisata Air Terjun Bajuinmemerlukan tanaman yang memiliki potensi sebagai tanaman hias untuk menambah daya tarik. Salah satu famili tumbuhan yang ada di kawasan Air Terjun Bajuin adalah Famili Palmae. Beberapa spesies Famili Palmae memiliki Potensi sebagai tanaman hias misalnya Areca catechu. Kajian tentang asosiasi tumbuhan dapat digunakan untuk melihat apakah ada hubungan antara satu spesies dengan spesies yang lain dalam suatu komunitas tumbuhan. Hal ini dapat dimanfaatkan untuk melihat pengaruh keberadaan suatu spesies terhadap spesies lain. Penelitian ini bertujuan untuk mengetahui asosiasi dan tipe interaksi antar spesies famili Palmae di kawasan Air Terjun Bajuin Kabupaten Tanah Laut. Penelitian ini adalah penelitian deskriptif menggunakan metode transek dengan observasi langsung. Plot yang digunakan berukuran $10 \times 10 \mathrm{~m}^{2}$. Jumlah titik pengambilan sampel adalah 40 titik. Asosiasi antar spesies tumbuhan ditentukan dengan tabel contingency 2x2. Adapun indeks asosiasi ditentukan dengan menghitung indeks Ochiai, Dice, dan Jaccard. Hasil penelitian menunjukkan ada 8 spesies yang ditemukan sehingga ada 28 kombinasi asosiasi antar spesies yang diuji. Berdasarkan hasil uji asosiasi, 25 kombinasi menunjukkan tidak ada asosiasi antar spesies. 3 kombinasi lainnya menunjukkan adanya asosiasi, dimana ada 2 asosiasi positif dan 1 asosiasi negatif.
\end{abstract}

Kata kunci: Asosiasi, Famili Palmae, Air Terjun Bajuin

\begin{abstract}
One of the recreation area in Tanah Laut Regency is Bajuin Waterfall. As one of the recreation area, Bajuin Waterfall require plants that have potential as an ornamental plant to increase power Pull. One of plants family in the Bajuin Waterfall area is Family Palmae. Some species of Family Palmae has Potential as an ornamental plant for example is Areca catechu. Studies about the association of plant can be used to study relationship between one species and another species in a plant community. It can be used to study the effect of the existence of a species to another species. The objectives of the research were to determine association and type of interactions between species family Palmae in the Bajuin Waterfall Tanah Laut Regency. This study was a descriptive study used transect method with direct observation. Plots size used was $10 \times 10 \mathrm{~m}^{2}$. The number of sampling points is 40 points. Associations between plant species is determined by $2 x 2$ contingency tables. The association index is determined calculated the index Ochiai, Dice and Jaccard. The results showed that eight species found there are 28 combinations of associations among species tested. Based on the test results of the association, 25 combination shows no association between species. 3 other combinations showed an association, where there are two positive associations and one negative associations.
\end{abstract}

Keywords: Association, Family Palmae, Bajuin Waterfall 


\section{PENDAHULUAN}

Air terjun Bajuin adalah salah satu kawasan wisata di Kabupaten Tanah Laut Provinsi Kalimantan Selatan. Air terjun ini terletak hanya $10 \mathrm{~km}$ dari pusat kota Pelaihari dan $75 \mathrm{~km}$ dari pusat kota Banjarmasin. Jarak air terjun Bajuin yang tidak terlalu jauh dari pusat kota menyebabkan air terjun Bajuin memiliki potensi untuk menarik pengunjung (Wisatawan). Selain itu, air terjun ini adalah salah satu air terjun yang terletak di kawasan lereng Pegunungan Meratus. Sebagai salah satu kawasan wisata, Air terjun Bajuin harus memiliki daya Tarik. Keberdaan suatu tumbuhan dapat menambah daya Tarik suatu kawasan. Hal ini karena tumbuhan dapat dijadikan sebagai tanaman hias yang berpotensi dan mempunyai nilai secara estitika. Salah satu famili tumbuhan yang berpotensi sebagai tanaman hias adalah Famili Palmae. Tumbuhan familia Palmae memiliki nilai estitika karena anggota familia ini memiliki bentuk dan warna organ tubuh yang bervariasi. Sehingga hal tersebut menjadikan familia Palmae berpotensi sebagai tanaman hias dan keunikan tersendiri. Salah satu contoh spesies familia Palmae yang memiliki bentuk daun yang unik adalah Caryota monostachya. Spesies ini memiliki bentuk bangun daun berupa segitiga terbalik.

Menurut Miranti et. al. (2014) pemanfaatan pinang merah sebagian besar sebagai tanaman hias. Pinang merah adalah salah satu anggota family Palmae. Menurut Dransfield et al. (2008) Palmae adalah salah satu family monokotil terbesar. Famili ini terdiri dari sekitar 200 marga dan 2600 Spesies, tersebar di Asia, Afrika, Amerika hingga Eropa. Manfaat lain dari famili Palmae adalah buah atau getahnya dapat diolah dan dikonsumsi. Menurut Damanik et al. (2014) tanaman Aren (Arenga pinnata Merr) merupakan salah satu tanaman yang termasuk hasil hutan non kayu dari suku Palmae yang memiliki nilai ekonomis dan bernilai tinggi. Karena seluruh bagian dari tanaman baik batang, daun, buah, dan ijuk yang dihasilkan dapat digunakan untuk keperluan kehidupan manusia. Hal ini menunjukkan bahwa family Palmae memiliki banyak potensi dan manfaat.

Hasil penelitian Arsyad (2014) menunjukkan bahwa di kawasan air terjun Bajuin ditemukan 8 spesies family Palmae. Selain itu berdasarkan pengukuran parameter lingkungan menunjukkan beberapa parameter lingkungan sesuai dengan kondisi abiotik untuk syarat hidup tumbuhan family Palmae. Misalnya pH tanah berkisar antara 6,49 - 8,79 dan kelembaban tanah berkisar antara 49,84\%-57,04\%. Menurut Staples (2006) spesies Palmae dapat tumbuh pada $\mathrm{pH} 8$. Hal ini menunjukkan bahwa kawasan Air Terjun Bajuin dapat menjadi habitat dari komunitas famili Palmae dengan berbagai spesies anggotanya. Suatu komunitas tumbuhan yang terdiri dari berbagai spesies memungkinkan terjadinya interaksi antar spesies pada komunitas tersebut. Misalnya ada tumbuhan yang hidup berkompetisi untuk mendapatkan nutrisi dari habitatnya. Kemudian contoh lain adalah ada tumbuhan yang hidup bergantung dengan tumbuhan yang lain untuk memperoleh nutrisi atau untuk memperoleh naungan.

Kurniawan et. al. (2008) menjelaskan ketertarikan tumbuhan untuk tumbuh bersama disebut dengan asosiasi. Asosiasi ada yang bersifat positif, negatif, atau tidak berasosiasi. Asosiasi positif terjadi bila suatu jenis tumbuhan hadir bersamaan dengan jenis tumbuhan lainnya; atau pasangan jenis terjadi lebih sering daripada yang diharapkan. Asosiasi negatif terjadi bila suatu jenis tumbuhan tidak hadir bersamaan 
dengan jenis tumbuhan lainnya; atau pasangan jenis terjadi kurang daripada yang diharapkan.

Keberadaan famili Palmae di kawasan Air Terjun Bajuin sudah pernah diteliti tetapi belum sampai kajian tentang asosiasi antar spesies. Oleh karena itu dilakukan penelitian tentang hal tersebut. Hal ini bertujuan untuk mempelajari asosiasi dan interaksi antar spesies famili Palmae sehingga diketahui jenis-jenis asosiasi antar tumbuhan tersebut baik yang bersifat positif maupun negatif. Penelitian tentang asosiasi dan interaksi dapat dimanfaatkan untuk menkaji salah satu faktor yang mempengaruhi pertumbuhan suatu tumbuhan, yaitu spesies tumbuhan dari familinya sendiri.

\section{METODE}

Jenis Penelitian ini adalah penelitian deskriptif. Pengambilan data dilakukan dengan cara observasi langsung. Penelitian ini dilakukan di kawasan Air Terjun Bajuin Desa Sungai Bakar Kabupaten Tanah Laut. Kawasan untuk pengambilan data ditentukan pada kawasan hutan dan pascaladang. Pada masing-masing kawasan, dilakukan pengambilan data dengan jalur transek dan menggunakan plot berukuran 10x10 $\mathrm{m}^{2}$. Penentuan titik untuk pembuatan plot dilakukan secara purposive. Beberapa spesies Palmae memiliki habitus berupa tegakan berupa pohon. Nurrahman et. al. (2012) menjelaskan bahwa ukuran plot untuk tegakan berupa pohon adalah $10 \times 10 \mathrm{~m}^{2}$. Pada setiap plot diamati keberadaan spesies tumbuhan famili
Palmae, kemudian dianalisis keberadaan kedua spesies yang diteliti asosiasinya. Jumlah plot pada penelitian ini adalah 40 plot.

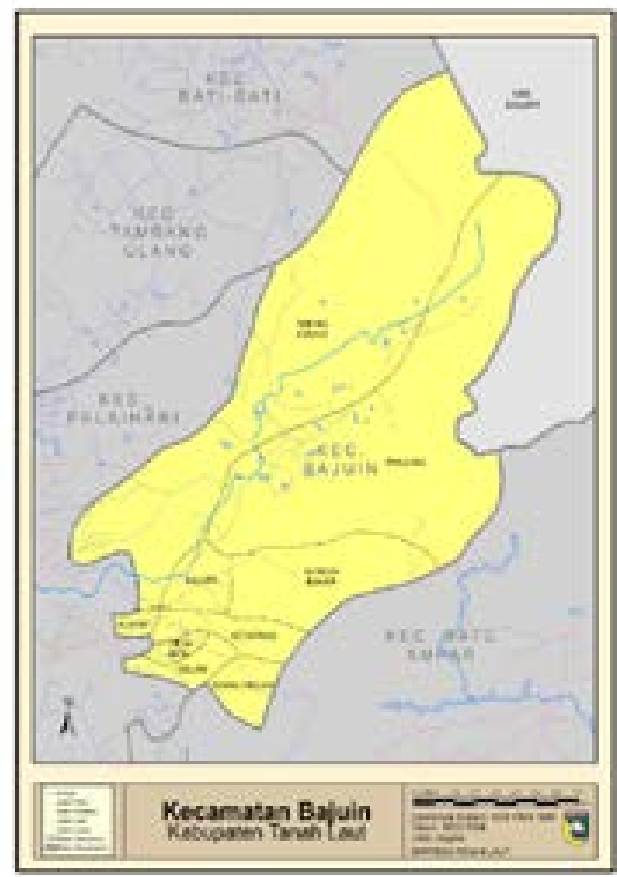

Gambar 1. Peta Kecamatan Bajuin

Adapun peta Desa Sungai Bakar dan Skema jalur transek serta posisi titik plot pada masing-masing jalur transek dapat dilihat pada gambar 2 dan 3 berikut ini.

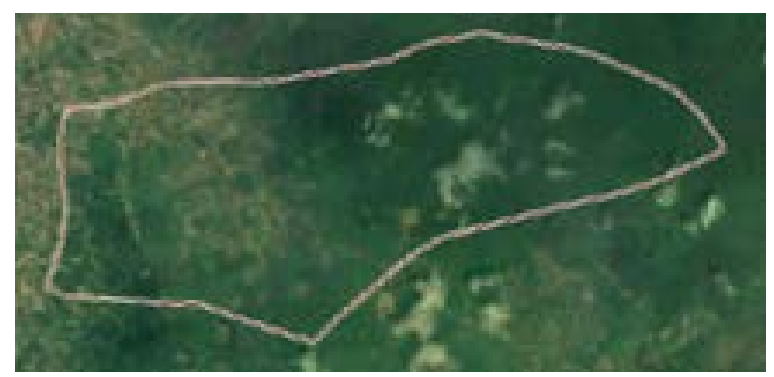

Gambar 2. Peta Desa Sungai Bakar 

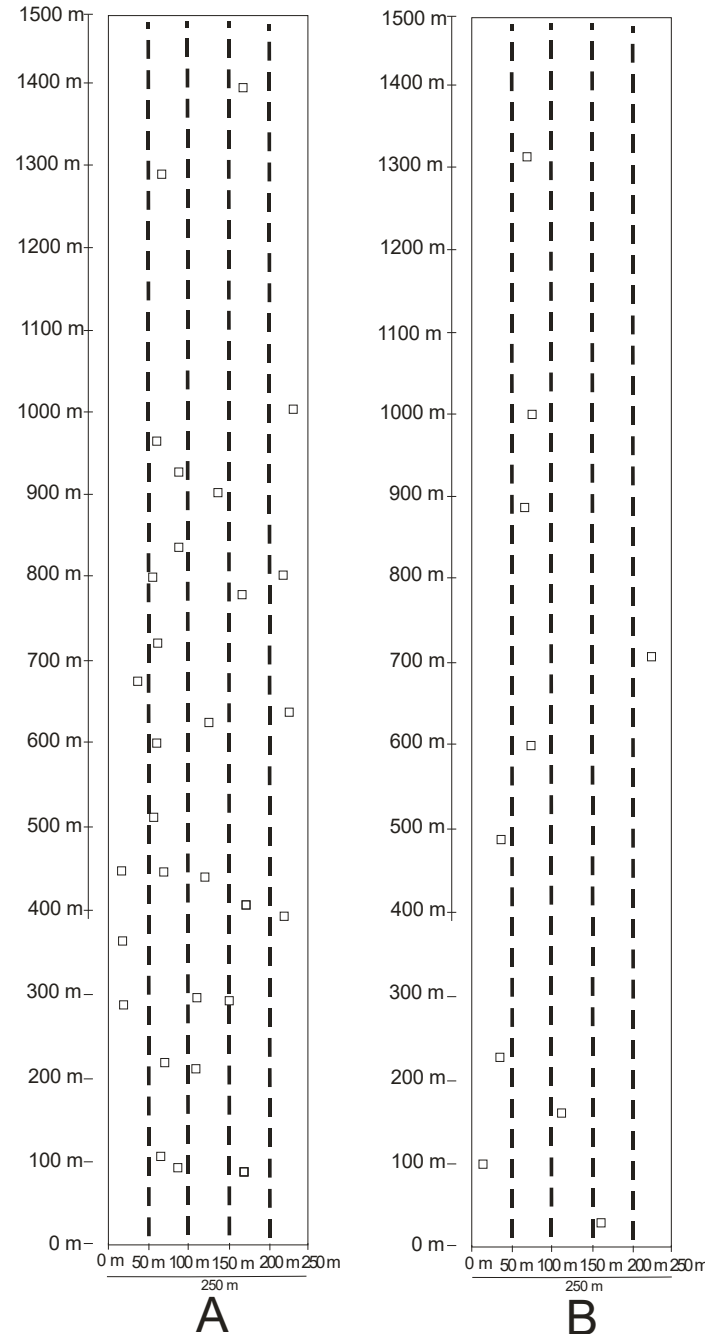

Gambar 3. Posisi Titik Plot untuk pengamatan pada masing-masing jalur tansek (A: Kawasan Hutan; B: Kawasan Pascaladang)

Asosiasi antar spesies tumbuhan ditentukan dengan tabel contingency $2 \times 2$ (tabel 1) (Greig-Smith, 1983). Penentuan ada tidaknya asosiasi antara satu spesies tumbuhan dengan spesies tumbuhan lain dihitung dengan nilai Chi-square $(\chi 2)$. Bila nilai $\chi 2$ Hitung $>\chi 2$ tabel berarti terjadi asosiasi, sebaliknya bila $\chi 2$ hitung $<\chi 2$ tabel berarti tidak terjadi asosiasi. Nilai $\chi 2$ tabeldengan derajat bebas satu pada tingkat 5\% adalah 3,84 (Ludwig and Reynolds, 1988).
Tabel 1. Tabel contingency $2 \times 2$

\begin{tabular}{|c|c|c|c|c|}
\hline & & & Jeni & \\
\hline & & Ada & $\begin{array}{c}\text { Tidak } \\
\text { Ada }\end{array}$ & Jumlah \\
\hline$\ll$ & Ada & A & B & $a+b=m$ \\
\hline$\stackrel{\Xi}{\Xi}$ & $\begin{array}{c}\text { Tidak } \\
\text { Ada }\end{array}$ & C & D & $\mathrm{c}+\mathrm{d}=\mathrm{n}$ \\
\hline & $\begin{array}{l}\text { Jum- } \\
\text { lah }\end{array}$ & $\begin{array}{c}a+c \\
=r\end{array}$ & $\begin{array}{c}b+d \\
=s\end{array}$ & $\mathrm{~N}=\mathrm{a}+\mathrm{b}+\mathrm{c}+\mathrm{d}$ \\
\hline
\end{tabular}

Tipe interaksi ditentukan dengan menghitung nilai $\mathrm{E}(\mathrm{a})$ (Ludwig dan Reynolds, 1988) dengan rumus

$$
E(a)=\frac{r m}{N}
$$

Jika a $>E(a)$ berarti asosiasi positif, dan jika $a<E(a)$ berarti asosiasi negatif. Adapun indeks asosiasi diuji dengan menghitung indeks Ochiai, Dice, dan Jaccard (Ludwig dan Reynolds, 1988) dengan rumus sebagai berikut:

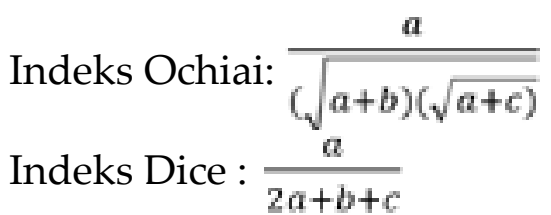

Indeks Jaccard : $\frac{a}{a+b+c}$

Asosiasi terjadi pada selang nilai 0-1, semakin mendekati angka 1 maka semakin kuat hubungan kedua jenis tersebut, demikian pula sebaliknya.

\section{HASIL DAN PEMBAHASAN}

Hasil perhitungan $X^{2}$ untuk menentukan ada tidaknya asosiasi antar spesies famili Palmae dapat dilihat pada Tabel 2. 
Tabel 2. Nilai $X^{2}$ pada masing-masing kombinasi asosiasi antar spesies

\begin{tabular}{|c|c|c|c|c|c|c|c|}
\hline \multicolumn{8}{|c|}{ Caryota monostachya } \\
\hline \multicolumn{8}{|c|}{5.403 Calamus ovoideus } \\
\hline 2.751 & 0.407 & \multicolumn{6}{|c|}{ Salacca edulis } \\
\hline 4.085 & 1.283 & 2.004 & \multicolumn{5}{|c|}{ Arenga caudate } \\
\hline 2.751 & 0.407 & 0.816 & 0.025 & \multicolumn{4}{|c|}{ Arenga pinnata } \\
\hline 1.562 & 1.562 & 0.463 & 0.447 & 0.463 & $\begin{array}{l}\text { Cham } \\
\text { ernest }\end{array}$ & $\begin{array}{l}\text { aedorea } \\
\text { iaugust }\end{array}$ & \\
\hline 0.985 & 1.283 & 1.212 & 0.061 & 0.025 & 0.688 & $\operatorname{Cocos}$ & ucifera \\
\hline 2.140 & 0.620 & 0.635 & 0.943 & 5.714 & 1.962 & 0.943 & $\begin{array}{l}\text { Areca } \\
\text { catechu }\end{array}$ \\
\hline
\end{tabular}

Adapun jenis interaksi pada perhitungan nilai $\mathrm{X}^{2}$ dapat dilihat pada masing-masing kombinasi berdasarkan tabel 3 berikut ini.

Tabel 3. Jenis asosiasi pada masing-masing kombinasi asosiasi antar spesies

\begin{tabular}{|c|c|c|c|c|c|c|c|}
\hline \multicolumn{8}{|c|}{ Caryota monostachya } \\
\hline \multirow{2}{*}{$\begin{array}{c}\text { Positif } \\
\text { Tidak ada }\end{array}$} & \multicolumn{7}{|c|}{ Calamus ovoideus } \\
\hline & Tidak ada & \multicolumn{6}{|c|}{ Salacca edulis } \\
\hline Negatif & Tidak ada & $\begin{array}{c}\text { Tidak } \\
\text { ada }\end{array}$ & \multicolumn{5}{|c|}{ Arenga caudate } \\
\hline Tidak ada & Tidak ada & $\begin{array}{c}\text { Tidak } \\
\text { ada }\end{array}$ & $\begin{array}{c}\text { Tidak } \\
\text { ada }\end{array}$ & \multicolumn{4}{|c|}{ Arenga pinnata } \\
\hline Tidak ada & Tidak ada & $\begin{array}{c}\text { Tidak } \\
\text { ada }\end{array}$ & $\begin{array}{c}\text { Tidak } \\
\text { ada }\end{array}$ & $\begin{array}{c}\text { Tidak } \\
\text { ada }\end{array}$ & \multicolumn{3}{|c|}{ Chamaedorea ernesti-augusti } \\
\hline Tidak ada & Tidak ada & $\begin{array}{c}\text { Tidak } \\
\text { ada }\end{array}$ & $\begin{array}{c}\text { Tidak } \\
\text { ada }\end{array}$ & $\begin{array}{c}\text { Tidak } \\
\text { ada }\end{array}$ & $\begin{array}{c}\text { Tidak } \\
\text { ada }\end{array}$ & Cocos & ucifera \\
\hline Tidak ada & Tidak ada & $\begin{array}{c}\text { Tidak } \\
\text { ada }\end{array}$ & $\begin{array}{c}\text { Tidak } \\
\text { ada }\end{array}$ & Positif & $\begin{array}{c}\text { Tidak } \\
\text { ada }\end{array}$ & $\begin{array}{c}\text { Tidak } \\
\text { ada }\end{array}$ & $\begin{array}{c}\text { Areca } \\
\text { catechu }\end{array}$ \\
\hline
\end{tabular}

Adapun perbandingan jumlah jenisjenis asosiasi antar spesies dapat dilihat pada gambar berikut ini

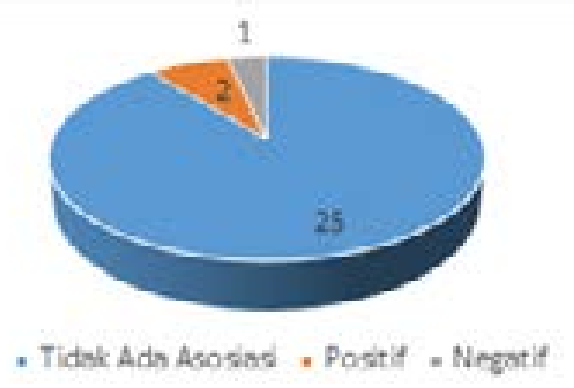

Gambar 4. Perbandingan Jenis-jenis Asosiasi antar Spesies
Hasil perhitungan Indeks Asosiasi dengn menggunakan Indeks Ochiai, Indeks Dice, dan Indeks Jaccard untuk mengetahui kekuatan asosiasi antar spesies dapat dilihat pada Tabel 4.

Berdasarkan hasil penelitian diketahui ada 2 kombinasi yang memiliki asosiasi positif. Kedua kombinasi tersbut yaitu Caryota monostachya dan Calamus ovoideu, dan Arenga pinnata dan Areca catechu. Selain dari nilai Indeks Ochiai, Indeks Dice, dan Indeks Jaccard, jenis interaksi positif antar spesies-speies tersebut juga dapat dilihat dari keberadaan kedua spesies yang berinteraksi yang ditemukan 
dalam satu plot pengamatan. Menurut Kurniawan et al. (2008) Asosiasi positif terjadi bila suatu jenis tumbuhan hadir bersamaan dengan jenis tumbuhan lainnya; atau pasangan jenis terjadi lebih sering daripada yang diharapkan. lebih lanjut Barbour et al. (1987) menjelaskan bila spesies berasosiasi positif maka akan menghasilkan hubungan spasial positif terhadap patnernya. Jika satu patner didapatkan dalam sampling, maka kemungkinan besar akan ditemukan patner lain tumbuh di dekatnya. Dua spesies saling beradaptasi satu sama lain dan hadir dalam pola mengelompok.

Tabel 4. Hasil Perhitungan Indeks Ochiai, Indeks Dice, dan Indeks Jaccard pada Spesies yang Berasosiasi

\begin{tabular}{|c|c|c|c|c|c|c|}
\hline & $\begin{array}{l}\text { Spesies yang } \\
\text { berasosiasi }\end{array}$ & & $\begin{array}{l}\text { Jenis } \\
\text { Asosi- } \\
\text { asi }\end{array}$ & IO & ID & IJ \\
\hline 1 & $\begin{array}{l}\text { Caryota } \\
\text { monostachya } \\
\text { dan Calamus } \\
\text { ovoideus }\end{array}$ & & Positif & 0.077 & 0.038 & 0.308 \\
\hline 2 & $\begin{array}{l}\text { Caryota } \\
\text { monostachya } \\
\text { dan Arenga } \\
\text { caudate }\end{array}$ & 0.5 & $\begin{array}{c}\text { Nega- } \\
\text { tive }\end{array}$ & 0.000 & 0.000 & 0.000 \\
\hline 3 & $\begin{array}{l}\text { Arenga pinna- } \\
\text { ta dan Areca } \\
\text { catechu }\end{array}$ & & Positif & 0.447 & 0.222 & 0.286 \\
\hline
\end{tabular}

Berdasarkan hasil penelitian dan uraian tersebut, maka peluang Caryota monostachya dan Calamus ovoideus, serta Arenga pinnata dan Areca catechu untuk ditanamdantumbuhbersama-samadalam satu kawasan sangat besar. Hal ini karena kedua spesies tersebut berpotesnsi untuk menghasilkan hubungan yang positif antara satu spesies dengan spesies yang lain. Bila dilihat dari nilai indeks asosiasi nilai indeks Asosiasi Arenga pinnata dan Areca catechu lebih besar dibandingkan nilai indeks asosiasi Caryota monostachya dan Calamus ovoideus. Hasil penelitian Ferita (2015) menunjukkan rata-rata tinggi batang Arenga pinnata berkisar antara $13,4 \mathrm{~m}$ sampai dengan $14,79 \mathrm{~m}$. Penelitian Simbolon (2013) menggunakan Pinang (Arecacatechu) dengan panjang batang 15 meter. Berdasarkan kedua penelitian tersebut, Arenga pinnata dan Areca catechu adalah spesies dengan habitus berupa pohon dengan panjang batang yang tidak jauh berbeda, sehingga diduga tidak terjadi kompetisi yang menyebabkan terjadinya asosiasi negatif misalnya dalam hal kompetisi memperoleh cahaya matahari.

Hasil penelitian Windusari et al. (2011) menunjukkan ada spesies yang berasosiasi karena kedua spesies yang berasosiasi tersebut menyukai tempat dengan parameter lingkungan yang hamper sama, misalnya tempat yang cenderung basah dan intensitas cahaya matahari yang tinggi hingga agak teduh. Lebihlanjutdijelaskan bahwa asosiasijenis dapat mempengaruhi keanekaragaman jenis pada hutan suksesi. 
Selain kombinasi dengan asosiasi positif, hasil penelitian juga menunjukkan adanya kombinasi dengan asosiasinegatif. Sofiah et al. (2013) menjelaskan pasangan spesies tidak selalu menghasilkan hubungan yang positif. Spesies tumbuhan yang memiliki frekuensi kehadiran yang tinggi, tidak selalu memberikan nilai asosiasi positif tinggi dengan spesies lain. Demikian halnya, spesies yang memiliki frekuensi kehadiran yang rendah tidak selalu memberikan asosiasi negatif dengan spesies lain. Pratama et al. (2012) menjelaskan Asosiasi negatif menunjukkan tidak adanya toleransi untuk hidup bersama pada area yang sama atau tidak adanya hubungan timbal balik yang saling menguntungkan. Keberadaan berbagai spesies dalam komunitas tumbuhan menimbulkan peluang terjadinya kompetisi, hal ini dijelaskan oleh Solikin (2015) keberadaaan beragam jenis tumbuhan dalam komunitas menyebabkan adanya kompetisi antar individu dalam spesies atau antar spesies yang pada akhirnya membentuk komposisi dan dominansi yang beragam.

Kombinasi asosiasi antar spesies yang memiliki asosiasi negatif adalah Caryota monostachya dan Arenga caudate. Berdasarkan perhitugan Indeks Jaccard, Indeks Ochiai, dan Indeks Dice, kekuatan asosiasi antar kedua spesies ini sangat lemah. Selain itu kedua spesies ini juga tidak kan dalam satu plot pengamatan secara bersama-sama.

Berdasarkan hasil penelitian, ada 25 kombinasi yang tidak memiliki asosiasi. Ada spesies yang tidak berasosiasi dengan tumbuhan lain karena tidak dipengaruhi oleh keberadaan spesies lainnya dan tumbuhan tersebut memiliki toleransi yang tnggi terhadap berbagai kondisi lingkungan. Menurut Sykora et al. (2014) kondisi fisik tanah mempengaruhi komposisi jenis tumbuha yang berasosiasi karena iklim mikro (cahaya, radiasi, angina, temperature dan kelembaban). Hasil penelitian Hidayat dan Juhaeti (2013) Asosiasi Alstonia spp di Taman Nasional Ujung Kulon menunjukkan Pulaikuning (A.scholaris) tidak berasosiasi dengan spesies tumbuhan lain penyusun habitatnya karena spesies ini toleran terhadap berbagai kondisi habitat.

\section{SIMPULAN, SARAN DAN REKOMENDASI}

Berdasarkan hasil penelitian ada 8 spesies yang ditemukan sehingga ada 28 kombinasi asosiasi yang diuji. Berdasarkan hasil uji asosiasi, 25 kombinasi menunjukkan tidak ada asosiasi antar spesies. 3 kombinasi lainnya menunjukkan adanya asosiasi, dimana ada 2 asosiasi positif dan 1 asosiasi negatif.

Perlu dilakukan penelitian lebiha lanjut tentang pengaruh pola distribusi dan faktor lingkungan terhadap Asosiasi Famili Palmae di kawasan air terjun Bajuin Kabupaten Tanah Laut.

\section{UCAPAN TERIMA KASIH}

Penulis mengucapkan terima kasih kepada tim ekologi Pendidikan Biologi PMIPA FKIP Universitas Lambung Mangkurat dan kepada pihak Laboratorium Biologi Umum Pendidikan Biologi PMIPA FKIP Universitas Lambung Mangkurat atas seluruh dukungan terhadap penelitian ini.

\section{DAFTAR PUSTAKA}

Arsyad, Muhammad, 2014. Struktur Vegetasi Famili Palmae pada Dua Habitat Pascaladang dan Hutan di Kawasan Air Terjun Bajuin Kalimantan Selatan. Jurnal Wahan-Bio. XII(2-2): 23-33

Barbour, G.M., J.K. Busk and W.D. Pitts. 1987.Terrestrial Plant Ecology. New York: The Benyamin/Cummings 
Publishing Company, Inc.

Damanik, Rionaldo, Irawati Azhar, Riswan, 2014. Inventory and Utilization Aren (A. pinnata) by Forest Communities Widely (Study Case: Sihombu Village, Tarabintang District, Humbang hasundutan Regency). Peronema Forestry Science Journal. 3(1): 18-24

Dansfield, J., N. W. Uhl, C. B. Asmussen, W. J. Baker, M. M. Harley, C. E. Lewis, 2008. Genera Palmarum: The Evolution and Classification of Palms. Royal Botanic garden, Kew. 732

Ferita, Istino, Tawarti, Zulfadli Syarif, 2015. Identifikasi dan Karakterisasi Tanaman Enau (Arenga pinnata) di Kabupaten Gayo Lues (Elektronik version). Prosiding Seminar Nasional Mayarakat Biodiversitas Indonesia. 1(1):31-37

Greig-Smith, P. 1983. Quantitative Plant Ecology. Iowa:University Press.

Hidayat, S. dan Juhaeti. T., 2013.Asosiasi alstonia sppdi taman nasional ujung kulon. Bionatura-jurnal ilmu-ilmu hayati dan fisik. 15(1): 44-48

Kurniawan, A., N.K.E, Undaharta dan I.M.R. Pendit. 2008. Asosiasi Jenisjenis Pohon Dominan di Hutan Dataran Rendah Cagar Alam Tangkoko, Bitung, Sulawesi Utara. Jurnal Biodiversitas. 9(3):199-203

Ludwig, J.A. and J.F. Reynolds. 1988. Statistical Ecology a Primer on Methods and Computing. San Diego, California: A Wiley-Interscience Publication

Miranti, Laili Fitri Yeni, Asriah Nurdini, 2014. Uji Potensi Anti Kanker Ekstrak Biji Pinang Merah dan Implementasinya dalam Pembelajaran Mitosis (Electornic version). Jurnal pendidikan dan Pembelajaran. 3(11)
Nurrahman, Yusuf Arief, Otong Suhara Djunaedi, Rita Rostika, 2012. Struktur dan Komposisi Vegetasi Mangrove di Pesisir kecamatan Sungai Raya Kepulauan Kabupaten Bengkayang Kalimantan Barat. Jurnal Perikanan dan Kelautan. 3(1): 99-107

Pratama, Bayu Arief, Laode Alhamd, Joeni Setijo Rahajoe, 2012. Asosiasi dan Karakterisasi Tegakan Pada Hutan Rawa Gambut di Hampagen, Kalimantan tengah. J. Tek. Ling. Edisi Khusus Hari lingkungan Hidup:69-76

Simbolon, Listi Erawaty, Tito Sucipto, Luthfi Hakim, 2013. Pemanfaatan Batang Pinang (Areca catechu Linn) sebagai Bahan Perekat Likuida Berdasarkan Kedalaman Batang. Peronema Forestry Science journal. 2(1): 111-116

Sofiah, Siti, Dede Setiadi, Didik Widyatmoko, 2013. Pola Penyebaran, Kemelimpahan, dan Asosiasi Bambu pada Komunitas Tumbuhan di Taman Wisata Alam Gunug Baung Jawa Timur. Berita Biologi. Jurnal Ilmu-Ilmu Hayati. 12(2): 239 -247

Solikin, 2015. Komposisi Jenisjenis Tumbuhan pada Dua Komunitas Tempat Tumbuh Stachytarphetajamaicensis (L.) Vahl. Di Desa Gajahrejo Kabupaten Pasuruan dan Desa Jeru Kabupaten Malang (Elektronik version).Bioeksperimen. 1(2): 28-36

Staples, George W. dan Robert F. Bevacqua. 2006. Areca catechu (betel nut palm). Species Profiles for Pacific Island Agroforestry

Sykora, K.V., J. C. van der Bogert,, F. Berendse, (2004). Change in Soil and Vegetation During Dune Slack Succession (Elektronik version) . J. Veget. Science, 15:209-218 
Bioeksperimen

Volume 3 No.1, (Maret 2017)

ISSN 2460-1365

Windusari, Yuanita, Robyanto H. Susanto,

PengendapanTailing Tanggul Ganda Zulkifli Dahlan, Wisno Susetyo, 2011. Asosiasi Jenis pada Komunitas Vegetasi Suksesi di Kawasan di Pertambangan PTFI Papua. Jurnal Ilmiah Ilmu-Ilmu Hayati Biota. 16(2): 242-251 